\title{
Peran Bimbingan Konseling Islam Mengatasi Kecanduan Game Online
}

\author{
Ardi ${ }^{1}$ * \\ ${ }^{1}$ MTs Muhammadiyah Sengkang, Kabupaten Wajo, Sulawesi Selatan, Indonesia. \\ * Korespondensi Penulis. E-mail: ardi@ gmail.com
}

\begin{abstract}
Abstrak
Bimbingan dan konseling Islami merupakan kegiatan proses bantuan yang diberikan kepada individu dalam memahami dirinya sendiri untuk menjalani tahap perkembangan menjadi manusia seutuhnya sebagaimana potensi yang dimilikinya sesuai petunjuk Allah dan sunnah Rasul. Terlihat sangat jelas bahwa bimbingan dan konseling Islami adalah proses bimbingan dan konseling yang berorientasi pada ketentraman, ketenangan hidup manusia di dunia dan di akhirat. Pencapaian rasa tentram (sakinah) itu tercapai melalui upaya pendekatan diri kepada Allah untuk memperoleh perlindungan-Nya. Dengan demikian, dapat dikatakan bahwa bimbingan dan konseling Islami mengandung aspek spiritual dan dimensi material. Salah satu tantangan di era revolusi industri 4.0 adalah kemajuan teknologi terutama TIK dengan munculnya smartphone. Kemajuan teknologi ini di satu sisi membantu dalam dunia pendidikan misalnya memudahkan siswa dan guru mendapatkan referensi pembelajaran dan penggunaan aplikasi ujian berbasis internet. Namun disisi lain tak dapat dipungkiri banyaknya pelajar mulai dari jenjang SD bahkan sampai jenjang perguruan tinggi mengalami kecanduan bermain game online. Permasalahan mengakses internet yang tidak terkendali pada diri remaja dipengaruhi oleh beberapa faktor, diantaranya karena perkembangan remaja yang masih labil, ketidakmampuan mengendalikan kecanduan bermain game online menyebabkan siswa malas belajar sehingga prestasi akademik dan kualitas kesehatannya menurun. Untuk mengatasi hal tersebut sangat dibutuhkan peran bimbingan konseling Islami. Bimbingan konseling Islami dengan metode yang bersumber dari al-Qur'an dan sunnah Rasulullah SAW seperti keteladanan Rasulullah SAW (modeling), conditioning, tazkiyatun nufus (penyucian jiwa) dan tazkiyatun nuqud (penyucian pendapatan/ibadah sosial) dapat menjadi solusi dalam mengatasi kecanduan game online.
\end{abstract}

Kata Kunci: Bimbingan Konseling Islam, Kecanduan Game Online, Metode Bimbingan

\section{The Role of Islamic Counseling Guidance Overcomes Online Game Addiction}

\begin{abstract}
Islamic guidance and counseling is an aid process activity that is given to individuals in understanding themselves to undergo the stage of development to become fully human as they have the potential according to Allah's instructions and the Sunnah of the Prophet. It is very clear that Islamic guidance and counseling is a process of guidance and counseling that is oriented to peace, the tranquility of human life in the world and in the hereafter. The attainment of peace (sakinah) is achieved through an effort to approach oneself to Allah to obtain His protection. Thus, it can be said that Islamic guidance and counseling contains spiritual aspects and material dimensions. One of the challenges in the era of industrial revolution 4.0 is the technological advances especially ICT with the advent of smartphones. The progress of this technology on the one hand helps in the world of education for example facilitating students and teachers to get reference to learning and the use of internet-based exam applications. But on the other hand, it cannot be denied that the number of students starting from elementary school even to college level is addicted to playing online games. The problem of uncontrolled access to the internet in adolescents is influenced by several factors, including because of the development of adolescents who are still unstable, the inability to control addiction to playing online games causes students to be lazy to learn so academic achievement and quality of health decreases. To overcome this, the role of Islamic counseling is urgently needed. Islamic counseling guidance with methods derived from the Qur'an and the Sunnah of the Prophet Muhammad, such as the example of the Prophet Muhammad (modeling), conditioning, tazkiyatun nufus (purification of the soul) and tazkiyatun nuqud (purification of income / social worship) can be a solution to overcome game addiction on line.
\end{abstract}

Keywords: Islamic Counseling Guidance, Online Game Addiction, Guidance Method 



\section{PENDAHULUAN}

Perkembangan teknologi komputer dan jaringan komputer merupakan dasar dari perkembangan Game Online. Meledaknya game online sendiri merupakan cerminan dari pesatnya jaringan komputer yang dahulunya berskala kecil (Small Local Network) sampai menjadi internet dan terus berkembang sampai sekarang. Game Online saat ini tidaklah sama seperti ketika game online diperkenalkan untuk pertama kalinya. Game adalah sesuatu yang dapat dimainkan dengan aturan tertentu sehingga ada yang menang dan ada yang kalah, biasanya dalam konteks tidak serius atau dengan tujuan refreshing. Game Online adalah game yang berbasis elektronik dan visual. ${ }^{1}$ Game Online dimainkan dengan memanfaatkan media visual elektronik yang biasanya menyebabkan radiasi pada mata, sehingga matapun lelah dan biasanya diiringi rasa sakit kepala.

Di era global, kemajuan suatu teknologi sangat berkembang pesat di seluruh dunia, tidak hanya pada kota-kota besar, tetapi kota-kota kecilpun juga. Dalam 10 tahun terakhir, permainan elektronik atau yang kita sering sebut dengan game online sudah menjamur dimana-mana. Game online itu sendiri tidak seperti warnet, mereka memiliki pelanggan tetap yang lebih banyak daripada warnet. Inilah yang membuat game center hampir selalu ramai dikunjungi. Game Online juga membawa dampak yang besar terutama pada proses pembelajaran siswa-siswi SD, SLTP, dan SLTA, pada keadaan siswa-siswi ketagihan dengan suatu game online, akan menyebabkan ia menjadi ketagihan atau kecanduan. Ketagihan memainkan game online akan berdampak buruk, terutama dari segi akademik dan sosialnya. Walaupun kita dapat bersosialisasi dalam game online dengan pemain lainnya, Game Online kerap membuat pemainnya melupakan kehidupan sosial dalam kehidupan sebenarnya. ${ }^{2}$

Bimbingan dan konseling dilaksanakan di sekolah dalam memaksimalkan potesi anak didik. Hal ini dilakukan agar segenap potesi yang di miliki anak, yaitu kecerdasan, bakat dan minat dikembangkan sesuai dengan karakteristik peserta didik. Tujuan umum bimbingan dan konseling adalah untukmembantu individu memperkembangkan diri secara optimal sesuai dengan ahap perkembangan yang dimilikinya seperti kemampuan dasar dan bakat, berbagai latar belakang yang ada seperti latar belakang keluarga, pendidikan dan status soasial ekonomi. ${ }^{3}$ Penjelasan tersebut memberikan makna bahwa pelaksanaan bimbingan dan konseling di sekolah harus diselengarakan untuk mengembangkan keperibadian peserta didik dalam upaya menghasilkan sumber daya manusia yang berkualitas dan beraqwa kepada Tuhan Yang Maha Esa.

Dalam Islam, bimbingan dan konseling merupakan bentuk bantuan yang bertujuan pada kemaslahatan. Bimbingan dan konseling Islami diberikan sebagai alternatif bagi pemecahan masalah kemanusiaan dan sosial yang semakin kompleks. Dengan memasukkan nilai-nilai dan ajaran agama, diharapkan manusia akan lebih dapat memahami dan menghadapi masalahnya secara lebih arif, tidak mudah putus asa dalam kegagalan dan tidak sombong dalam keberhasilan atau dengan kata lain tidak berlebih-lebihan pada segala hal dalam hidupnya. Bimbingan dan konseling Islami adalah proses pemberian bantuan terhadap individu agar mampu hidup selaras dengan ketentuan dan petunjuk Allah sehingga dapat mencapai kebahagiaan hidup di dunia dan akhirat. ${ }^{4}$ Sebagai makhluk yang sering menghadapi masalah, manusia telah dibekali akal pikiran dan perasaan serta diberi petunjuk bagi pemecahan persoalan dalam kehidupannya. Akan tetapi, karena tidak semua problem dapat diselesaikan oleh manusia secara mandiri, ia memerlukan bantuan seorang ahli yang berkompeten sesuai dengan jenis problem yang dihadapinya.

Dalam hal ini kesempurnaan ajaran Islam menyimpan khazanah-khazanah berharga yang dapat digunakan untuk membantu menyelesaikan problem yang dihadapi manusia dalam kehidupannya. Secara operasional, khazanah-khazanah tersebut tertuang dalam konsep-konsep Islami yang secara praktis tercermin dalam proses hubungan atau pertemuan tatap muka.

${ }^{1}$ Tumiyem Tumiyem and Dessy Nita Sembiring, "Program Bimbingan Dan Konseling Dalam Mengurangi Kecanduan Game Online Oleh Siswa Kelas VIII SMP Melati Binjai Tahun Pelajaran 2017/2018," Al-Irsyad 8, no. 1 (2018).

2 Tumiyem and Sembiring.

${ }^{3}$ Abu Bakar M Luddin, Dasar Dasar Konseling (Perdana Publishing, 2010).

${ }^{4}$ Ainur Rahim Faqih, Bimbingan Konseling Islam (Yogyakarta: UII Press, 2004). 
Tatanan bimbingan dan konseling Islami merupakan kegiatan proses bantuan yang diberikan kepada individu dalam memahami dirinya sendiri untuk menjalani tahap perkembangan menjadi manusia seutuhnya sebagaimana potensi yang dimilikinya sesuai petunjuk Allah dan sunna Rasul. Terlihat sangat jelas bahwa bimbingan dan konseling Islami adalah proses bimbingan dan konseling yang berorientasi pada ketentraman, ketenangan hidup manusia di dunia dan di akhirat. Pencapaian rasa tentram (sakinah) itu tercapai melalui upaya pendekatan diri kepada Allah untuk memperoleh perlindungan-Nya. Dengan demikian, dapat dikatakan bahwa bimbingan dan konseling Islami mengandung aspek spiritual dan dimensi material. Dimensi spiritual adalah membimbing manusia pada kehidupan rohaniah untuk menjadi beriman dan bertakwa kepada Allah. Sedangkan dimensi material membantu manusia untuk dapat memecahkan masalah kehidupan agar dapat mencapai kebahagiaan selama hidupnya. Prinsip-prinsip inilah yang dengan tegas membedakan konsep bimbingan dan konseling Islami dengan prinsip bimbingan dan konseling konvensional yang dihasilkan dari pengetahuan empirik barat.

Sejalan dengan perkembangan teknologi yang sekarang dengan istilah revolusi industri 4.0 yang juga turut menyentuh dimensi pendidikan. Proses pendidikan di sekolah atau di madrasah tentu harus mengikuti perkembangan teknologi tersebut yang tentunya memiliki sisi positif dan negatif. Salah satu kemajuan teknologi adalah munculnya smartphone dan internet murah melalui jaringan $4 \mathrm{G}$ yang sekarang sudah sampai ke pelosok-pelosok desa. Sehingga akses internet dengan smartphone bukan lagi sesuatu yang mahal. Kondisi ini tentunya memudahkan remaja mengakses aplikasi sosial media (whaats up, facebook, instagram dll), browsing google dan youtube serta aplikasi game online. Kemajuan teknologi ini di satu sisi membantu dalam dunia pendidikan misalnya memudahkan siswa dan guru mendapatkan referensi pembelajaran dan penggunaan aplikasi ujian berbasis internet. Namun disisi lain tak dapat dipungkiri banyaknya pelajar mulai dari jenjang SD bahkan sampai jenjang perguruan tinggi mengalami kecanduan bermain game.

Permasalahan mengakses internet yang tidak tepat pada diri remaja dipengaruhi oleh beberapa faktor, diantaranya karena perkembangan remaja yang masih labil. ${ }^{5}$ Young mengatakan dengan terlibat dalam aktifitas penggunaan internet, remaja mencari kompensasi untuk identitas diri, harga diri, dan jaringan sosial. ${ }^{6}$ Ketidakmampuan mengatur aspek kehidupan pada diri siswa disebabkan terus meningkatnya kesenangan siswa menggunakan internet yang berimplikasi pada ketidakmampuan siswa disiplin dalam belajar. Internet menjadi lebih dominan daripada kegiatan belajar sehingga hal tersebut menurunkan prestasi akademik siswa.

Berdasarkan pengamatan penulis, sejak maraknya penggunaan smartphone apalagi sejak munculnya warung kopi (warkop) yang memberikan fasilitas wifi gratis (free wifi), banyak siswa termasuk di MTs. Muhammadiyah Sengkang menghabiskan waktu di warkop sepulang sekolah bahkan ada yang sampai bolos jam pelajaran untuk bermain game online. Fenomena ini tentunya membuat mereka kehabisan waktu belajar, mengantuk sehingga terlambat ke sekolah dan prestasi akademiknya menurun bahkan ada yang sampai harus berhenti sekolah karena di dropout oleh pihak sekolah. Bahkan lebih parah lagi dalam pemberitaan harian terdapat Sepuluh anak di Banyumas didiagnosa mengalami gangguan mental akibat kecanduan bermain game online sepanjang tahun 2018. Mereka mendapat terapi di RSUD Banyumas. 7 dari 10 anak itu merupakan siswa Sekolah Dasar (SD) dan Sekolah Menengah Pertama (SMP).

Sebagai pendidik dan psikolog pendidikan, guru bimbingan konseling perlu merancang layanan yang cepat dan responsif dalam mengatasi berbagai persoalan-persoalan yang dialami oleh pelajar seperti kecanduan game online. Layanan responsif adalah layanan bantuan yang diberikan kepada siswa yang menghadapi masalah yang perlu segera diselesaikan, sebab jika tidak diselesaikan akan berdampak negatif pada terhambatnya tugas perkembangan siswa. Peran guru bimbingan konseling dalam membantu siswa yang mengalami kecanduan game online diantaranya melalui pemberian layanan konseling baik secara individu maupun kelompok.

Konseling sebagai hubungan antara seorang helper yang terlatih dengan seorang yang mencari bantuan untuk mengatasi masalah, mendefenisikan tujuan, kemudian menempuh serangkaian langkah

5 Rischa Pramudia Trisnani and Silvia Yula Wardani, "Peran Konselor Sebaya Untuk Mereduksi Kecanduan Game Online Pada Anak," Dialektika Masyarakat: Jurnal Sosiologi 2, no. 2 (n.d.): 71-80.

${ }^{6}$ Trisnani and Wardani. 
treatment untuk memperoleh hasil yang diharapkan. ${ }^{7}$ Lebih lanjut disebutkan bahwa hasil yang diharapkan dapat diartikan sebagai perkembangan dan pertumbuhan yang meliputi: kompetensi intra dan interpersonal, pertumbuhan kepribadian dan penyelesaian masalah yang dihadapi konseli yang teridentifikasi secara spesifik. Tiga unsur makna penting dalam konseling yakni hubungan yang membantu, identifikasi masalah, tujuan dan treatment (perlakuan). Oleh karena itu, diperlukan sebuah pendekatan spesifik dalam melakukan konseling, agar konseling yang dilakukan dapat berlangsung efektif dan tepat sasaran.

Sejalan dengan bimbingan dan konseling konvensional, bimbingan dan konseling Islami mengandalkan adanya hubungan personal antar manusia, satu pihak yang ingin memecahkan masalah, dan pihak lain yang membantu menyelesaikan masalah tersebut. Dalam hal ini, Bimbingan dan konseling Islami adalah "bimbingan kehidupan yang pada intinya tertuju pada realisasi doa rabbana atina fi ad-dunya hasanah wa fil al-akhirati hasanah wa qina adzaba an-nar, berisikan rintisan jalan ke arah penyadaran kepribadian manusia sebagai makhluk Allah dan dapat menumbuhkan rasa tentram dalam hidup karena selalu merasa dekat dengan Allah dan ada dalam lindung-Nya. ${ }^{8}$

Bimbingan dan konseling Islam adalah proses pemberian bantuan terhadap individu agar menyadari kembali eksistensinya sebagai makhluk Allah yang seharusnya hidup selaras dengan ketentuan dan petunjuk Allah, sehingga dapat mencapai kebahagiaan di dunia dan di akhirat. Bimbingan dan konseling Islam merupakan proses bimbingan sebagaimana kegiatan bimbingan lainnya, tetapi dalam seluruh seginya berlandaskan ajaran Islam, artinya berlandaskan Al-Qur'an dan Sunnah Rasul. Bimbingan dan konseling Islam merupakan proses pemberian bantuan, yang tidak menentukan atau mengharuskan, melainkan sekedar membantu individu. Individu dibantu, dibimbing agar mampu hidup selaras dengan ketentuan dan petunjuk Allah.

Salah satu bentuk layanan bimbingan dan konseling melalui layanan pembelajaran. Menurut Prayitno bahwa layanan pembelajaran adalah bimbingan dan konseling yangmemungkinkan peserta didik (klien) mengembangkan diri berkenaan dengan sikap dan kebiasaan belajar yang baik, materi belajar yang cocok, dengan kecepatan dan kesulitan belajarnya, serta berbagai aspek tujuan dan kegiatan belajar lainnya. ${ }^{9}$ Layanan pembelajaran adalah layanan bimbingan dan konseling yang memungkinkan individu mengembangkan diri berkenaan dengan sikap dan kebiasaan belajar yang efektif dan efesien, materi belajar yang cocok, kecepatan dan kesulitan belajar. Fungsi utama bimbingan yang di dukung oleh layanan pembelajaran adalah fungsi pemeliharaan dan fungsi pengembangan.

Layanan bimbingan kelompok ialah layanan bimbingan dan konseling yang memungkinkan sejumlah siswa secara bersama melalui dinamika kelompok memperoleh berbagai bahan dari nara sumber tertentu (terutama guru pembimbing) atau membahas topik tertentu yang berguna untuk menunjang pemahaman dalam kehidupan atau pertimbangan dalam pengambilan keputusan atau tindakan tertentu. ${ }^{10}$ Layanan bimbingan dapat diselenggarakan baik secara perseorangan atau kelompok. Secara perorangan layanan konseling dilaksanakan melalui konseling perorangan atau layanan konsultasi dan secara kelompok melalui layanan bimbingan kelompok (BKP). Menurut Prayitno "Layanan bimbingan kelompok tersebut mengikutkan sejumlah peserta dalam bentuk kelompok, dengan konselor sebagai pemimpin kegiatan kelompok. ${ }^{11}$ Layanan bimbingan konseling kelompok ialah layanan yang dilakukan dalam suasana kelompok. Layanan ini memungkinkan siswa memperoleh kesempatan dari pembahasan dan pengentasan masalah yang dialami melalui dinamika kelompok. ${ }^{12}$

Secara umum game merupakan suatu bentuk permainan. Game tidak terbatas pada barang elektronik. Game online adalah suatu bentuk permainan yang dihubungkan melalui jaringan internet. Jadi, yang dimaksud dengan game online adalah sebuah permainan yang dimainkan dengan sambungan

${ }^{7} \mathrm{M}$ E Cavanagh and J E Levitov, The Counseling Experience: A Theoretical Approach (Illinois: Waveland Press, 2002).

${ }^{8}$ M D Dahlan and Dasar-Dasar Konseptual Penanganan Masalah-Masalah, "Bimbingan Dan Konseling Islami Di Bidang Pendidikan” (Yogyakarta: UII Press, 1987).

${ }^{9}$ H Kamaluddin, "Bimbingan Dan Konseling Sekolah,” Jurnal Pendidikan Dan Kebudayaan 17, no. 4 (2011): 447-54.

${ }^{10}$ Mochamad Nursalim and S A Suradi, Layanan Bimbingan Dan Konseling (Surabaya: Unipress, 2002).

${ }^{11}$ Kamaluddin, "Bimbingan Dan Konseling Sekolah."

${ }^{12}$ K Komarudin, "Mengungkap Landasan Filosofis Keilmuan Bimbingan Konseling Islam,” International Journal Ihya' 'Ulum Al-Din 17, no. 2 (2017): 209-32. 
internet melalui jaringan komputer (computer network), bisa menggunakan PC (personal computer), atau konsol game biasa, dan biasanya dimainkan oleh banyak pemain dalam waktu yang bersamaan dimana antar pemain bisa saling tidak mengenal.

Games berkembang dengan sangat cepat, berawal dari single-players game lalu ke multi-players game. Game Mario Bross, Tetris, Contra, dan Space War adalah beberapa game single/double-players game yang cukup terkenal. Game ikut berkembang setelah tahun 1990an internet mulai dikenal. Game tidak lagi dimainkan secara sederhana dengan sistem single/double-players, game telah dimainkan dengan jaringan internet atau lebih dikenal dengan game online. Games online tidak terbatas pada perangkat yang digunakan. Games online bisa dimainkan di komputer, laptop, smartphone, bahkan di tablet sekalipun. Games online juga tidak terbatas pada bentuk, geme bisa dimainkan di sosial media seperti facebook, twitter, bahkan friendster ataupun google+.

Definisi mengenai kecanduan Game Online menurut Young adalah sebagai berikut: "an activity or substance we repeated crave to experience, and for which we are willing if necessary to pay a price (or negative consequence)". Berdasarkan defenisi tersebut kecanduan berarti suatu aktivitas atau substansi yang dilakukan berulang-ulang dan menimbulkan dampak negatif. Lebih lanjut Yee mengatakan "Kecanduan adalah suatu perilaku yang tidak sehat yang berlangsung terus menerus yang sulit diakhiri oleh individu yang bersangkutan".

Dengan memperhatikan definisi tersebut, maka dapat ditarik kesimpulan bahwa kecanduan game online adalah suatu aktivitas atau substansi terhadap suatu jenis permainan komputer berupa game online yang dilakukan berulang - ulang dan dapat menimbulkan dampak negatif. Khusus anak yang masih dibangku sekolah, perlu menjadi bahan perhatian akibat kecanduan game online. Sesuatu yang dilakukan secara berlebihan tidak akan pernah berujung dengan baik. Anak yang sudah kecanduan game online perlu diatasi dengan pemberian manajemen waktu seperti belajar dan bermain agar anak dapat mengatur waktu belajar dan bermainnya dengan baik sehingga lebih efektif dan efisien. Mengatur anak untuk sesuatu agar terorganisasi dengan baik akan membentuk anak yang displin dan lebih bertanggung jawab.Menurut Yee, terdapat empat komponen kecanduan game online, yakni excessive use, withdrawal symptoms, tolerance and negative respercussions.

Berdasarkan kerangka konseptual di atas, maka konsep dalam penelitian ini adalah apakah program bimbingan dan konseling yang dilakukan oleh guru bimbingan dan konseling dapat mengatasi kecanduan siswa terhadap game online. Disini program bimbingan dan konseling yang digunakan guru adalah layanan bimbingan kelompok. Adapun pernyataan dalam penelitian ini adalah : Apakah Program Bimbingan dan Konseling Dalam Mengurangi Kecanduan Game Online Oleh Siswa Kelas VIII SMP Melati Binjai Tahun Pelajaran 2017/2018?.

\section{PEMBAHASAN}

\section{Pengertian Bimbingan dan Konseling Islam}

Secara etimologis, Bimbingan dan Konseling terdiri atas dua kata yaitu "bimbingan" (terjemahan dari kata guidance) dan "konseling" (diadopsi dari kata counseling). Secara harfiah istilah "guidance" dari akar kata "guide" berarti mengarahkan (to direct), membantu (to pilot), mengelola (to manage), dan menyetir (to steer). Dari segi pengertian bimbingan adalah bantuan atau pertolongan yang diberikan kepada individu atau sekelompok dalam menghindari atau mengatasi kesulitan-kesulitan dalam hidupnya, agar individu atau kelompok itu dapat mencapai kesejahteraan hidupnya.

Secara parsial, konseling dalam bahasa inggris adalah Counseling dikaitkan dengan kata Counsel yang diartikan sebagai berikut: nasihat (to abtain counsel), anjuran (to give counsel), pembicaraan (to take counsel). Dengan demikian konseling dapat diartikan sebagai pemberian nasihat, pemberian anjuran, dan pembicaraan dengan bertukar pikiran.

Konseling merupakan pelayanan terpenting dalam program bimbingan. Layanan ini memfasilitasi untuk memperoleh bantuan pribadi secara langsung untuk mengatasi masalah yang timbul pada siswa. Bimbingan dan Konseling Islam adalah suatu proses pemberian bantuan kepada konseli yang berupa informasi yang bersifat preventif sehingga konseli dapat memahami dirinya dan dapat mengenali lingkungannya. Konseling Islam adalah proses pemberian bantuan yang berdasarkan Qur'an dan hadits, 
unuk menjadi penerang bagi bagi seluruh umat manusia. Guna mengantarkan manusia kepada kebahagiaan lahir batin dunia dan akhirat. ${ }^{13}$

Bimbingan konseling islam adalah suatu aktivitas dalam memberikan bimbingan, pelajaran, dan pedoman kepada individu yang meminta bimbingan dalam hal bagaimana seharusnya seorang konseli dapat mengembangkan potensi akal pikirannya, kejiwaannya, keimanan dan keyakinan serta dapat menanggulangi problematika hidup dan kehidupannya dengan baik dan Sunnah Rasulullah SAW. ${ }^{14} \mathrm{Jadi}$ dapat disimpulkan bahwa bimbingan konseling islam adalah suatu proses pemberian bantuan kepada individu atau kelompok agar ia memahami dirinya dan dunianya sesuai Al-Qur'an dan Sunnah.

\section{Tujuan Bimbingan dan Konseling Islam}

Secara garis besar tujuan bimbingan dan konseling Islam dapat dirumuskan untuk membantu individu mewujudkan dirinya sebagai manusia seutuhnya agar mencapai kebahagiaan hidup di dunia dan diakhirat. Sedangkan tujuan dari bimbingan dan konseling dalam Islam yang lebih terperinci adalah untuk menghasilkan suatu perbuatan, perbaikan, kesehatan, dan kebersihan jiwa dan mental. ${ }^{15}$ Jiwa menjadi tenang, jinak dan damai, bersikap lapang dada dan mendapatkan pencerahan, taufik dan hidayah Tuhannya.

\section{Fungsi Bimbingan dan Konseling Islam}

Adapun fungsi bimbingan konseling Islam menurut Aunur Rahim Faqih dikelompokan menjadi tiga bentuk, yaitu: Fungsi preventif, membantu individu menjaga atau mencegah timbulnya masalah bagi dirinya; Fungsi kuratif, membantu individu memecahkan masalah yang sedang dihadapi atau dialaminya; Fungsi preservatif, membantu individu menjaga agar situasi dan kondisi yang semula tidak baik (mengandung masalah) menjadi baik (terpecahkan) dan kebaikan itu bertahan lama; dan Fungsi developmental atau pengembangan, membantu individu memelihara dan mengembangkan situasi dan kondisi yang telah baik agar tetap baik atau menjadi lebih baik, sehingga tidak memungkinkanya menjadi sebab munculnya masalah baginya.

\section{Pengertian Kecanduan Game Online dan Akibat yang Ditimbulkan}

Kecanduan atau addiction dalam kamus psikologi diartikan sebagai keadaan ketergantungan secara fisik pada suatu obat bius. Kata kecanduan (addiction) biasanya digunakan dalam konteks klinis dan diperhalus dengan prilaku berlebihan. Konsep kecanduan dapat diterapkan pada prilaku secara luas termasuk kecanduan teknologi komunikasi dan informasi.

Menurut Tracy LaQuey semua permainan mengharuskan ditempuhnya proses belajar yang sungguh-sungguh untuk mengenal tokoh dan keanehan pemainnya dan peraturannya. ${ }^{16}$ Hampir semua permainan game menimbulkan kecanduan. Bahkan pemainnya kadang menghabiskan waktunya berjamjam. Game online adalah game yang berbasis elektronik visual. Game online dimainkan dengan memanfaatkan media visual elektronik yang biasanya menyebabkan radiasi pada mata, sehingga mata menjadi lelah dan biasanya diiringi dengan sakit kepala. Jadi kecanduan game online adalah suatu keadaan seseorang yang terikat pada kebiasaan yang sangat kuat dan tidak bisa lepas untuk bermain game online, dari waktu ke waktu akan terjadi peningkatan durasi atau frekuensi tanpa memperdulikan akibat negatif yang akan ditimbulkan pada dirinya.

Dampak seseorang yang mengalami kecanduan terhadap video atau permainan berbasis internet (game online) sangat besar. Seseorang yang mengalami adiksi, di samping mengalami keluhan secara fisik juga mengalami perubahan struktur dan fungsi otak. Struktur dan fungsi otaknya mengalami perubahan. Jadi, kalau kita lihat otaknya pake MRI, ada perubahan di bagian otak pre-frontal cortex". Gangguan pada bagian otak tersebut mengakibatkan orang yang mengalami suatu ketergantungan atau kecanduan kehilangan beberapa kemampuan/fungsi otaknya, antara lain fungsi atensi (memusatkan

\footnotetext{
${ }^{13}$ Komarudin.

14 M Hamdani Bakran Adz-Dzaky and Ahmad Norma-Permata, Psikoterapi \& Konseling Islam: Penerapan Metode Sufistik (Fajar Pustaka Baru, 2001).

${ }^{15}$ Isep Zainal Arifin, "Bimbingan Konseling Islam (Al-Irsyad Wa Al-Tawjîh Al-Islam) Berbasis Ilmu Dakwah," Ilmu Dakwah: Academic Journal for Homiletic Studies 4, no. 11 (2008): 27-42.

${ }^{16}$ Tracy Laquey, The User's Directory of Computer Networks (Elsevier, 2014).
} 
perhatian terhadap sesuatu hal), fungsi eksekutif (merencanakan dan melakukan tindakan) dan fungsi inhibisi (kemampuan untuk membatasi). Selain berperilaku impulsive, bisanya orang yang kecanduan video/game online kehilangan fokus saat mengerjakan sesuatu sehingga berdampak pada prestasi dan produktivitasnya. Emosi yang tidak stabil juga seringkali berdampak buruk pada hubungan relasinya. Sehingga sebagian besar para pecandu video/game online menunjukkan sikap yang antisosial. Sementara itu, dari sisi kesehatan, orang yang kecanduan game online seringkali mengalami gangguan tidur sehingga mempengaruhi sistem metabolisme tubuhnya, sering merasa lelah (fatigue syndrome), kaku leher dan otot, hingga Karpal Turner Syndrome. Selain itu, kecenderungan sedentary life dan memprioritaskan bermain game dibandingkan aktifitas utama lainnya (misalnya makan), membuat para pecandu game online mengalami dehidrasi, kurus atau bahkan sebaliknya (obesitas) dan berisiko menderita penyakit tidak menular (misalnya penyakit jantung).

Organisasi kesehatan dunia atau Word Health Organization (WHO) telah menetapkan kecanduan game online atau game disorder ke dalam versi terbaru International Statistical Classification of Diseases (ICD) sebagai penyakit gangguan mental (mental disorder). Dalam versi terbaru ICD-11, WHO menyebut bahwa kecanduan game merupakan disorders due to addictive behavior atau gangguan yang disebabkan oleh kebiasaan atau kecanduan.

Seseorang dikatakan online/video gaming disorder bila memenuhi kriteria yang telah ditetapkan, yaitu adanya perilaku berpola dengan karakteristik sebagai berikut: 1) Ada gangguan kontrol untuk melakukan permainan tersebut (tidak dapat mengendalikan diri); 2) Lebih memprioritaskan memainkan permainan tersebut dibandingkan dengan aktivitas yang seharusnya lebih diutamakan; 3) Intensitasnya semakin meningkat dan berkelanjutan meskipun ada konsekuensi atau dampak negatif yang dirasakan; 4) Perilaku berpola tersebut menyebabkan gangguan yang bermakna pada fungsi pribadi, keluarga, sosial, pendidikan dan area penting lainnya; serta 5) pola tersebut sudah belangsung selama 12 bulan.

\section{Metode-Metode Bimbingan Konseling Islam yang Bisa Digunakan untuk Mengatasi Kecanduan Game Online}

Bimbingan dan konseling Islam merupakan perpaduan dari bimbingan dan konseling konvensional dengan pemikiran yamg menyandarkan argumen pada al-qur'an dan hadist sesuai dengan keteladanan nabi Muhammad. ${ }^{17}$

\section{Keteladanan (modeling)}

Melalui metode keteladanan (modeling) dari akhlak Rasulullah SAW, yang dimulai dari guru bimbingan dan konseling Islam terlebih dahulu. Guru BK Islam harus menanamkan akhlak Rasulullah SAW, kepada siswanya. Guru BK Islam dan pendidik lainnya harus membiasakan terlebih dahulu akhlak Rasulullah SAW dalam kehidupan sehari-harinya sehingga siswanya bisa meneladaninya. Guru BK Islam harus memastikan siswanya mengenali akhlak Rasulullah SAW dan sahabat-sahabat beliau yang dikenal dengan Khulafaur Rasyidin. Siswa harus memahami dan mengidolakan Rasululullah dan sahabatnya dalam kehidupan sehari-harinya. Hal ini sejalan dengan firman Allah dalam Al-Qur'an surat al-Ahzab ayat 21: yang artinya, "Sesungguhnya telah ada pada diri Rasulullah itu suri tauladan yang baik bagimu, yaitu bagi orang-orang yang mengharap rahmat Allah dan kedatangan hari kiamat dan dia banyak menyebut Allah.". melalui metode modeling dengan materi shirah nabawiyah diharapkan siswa dapat mengurangi kecanduan game online.

\section{Conditioning}

Conditioning dalam sejarah Islam merupakan sintesis dari pelbagai peristiwa yang meliputi: Pertama, peristiwa Perang Badar pada tahun 2 Hijriyah. Dalam perang tersebut, kaum muslimin jelas kalah dalam hal jumlah dibandingkan dengan pasukan kafir Quraisy waktu itu, tetapi dengan izin Allah, melalui proses pengondisian, akhirnya kaum muslimi dapat memenangkan perang tersebut. Dalam Alqur'an surat Ali Imran ayat 166 yang artinya,"Dan apa yang menimpa kamu pada hari bertemunya dua pasukan, maka (kekalahan) itu adalah dengan izin Allah (takdir) Allah, dan agar Allah mengetahui siapa orang-orang yang beriman”.

${ }^{17}$ Ganda Yogi Wiguna and Yohanes Kartika Herdiyanto, "Coping Pada Remaja Yang Kecanduan Bermain Game Online,” Jurnal Psikologi Udayana 5, no. 3 (2018): 669-78. 
Kedua, turunnya perintah puasa dan salat lima waktu sebagai proses pengondisian kaum muslim untuk selalu mendekatkan diri pada Allah. Perintah untuk melakukan salat dan puasa sangat ditegaskan dalam al-Qur'an surat al-Baqarah ayat 45 yang artinya, "jadikanlah sabar dan shalat sebagai penolongmu. Dan sesungguhnya yang demikian itu sungguh berat, kecuali bagi-orang-orang yang khusyu". Guru bimbingan konseling Islam dapat menggunakan pembiasaan shalat fardhu, puasa sunnah, tadarrus al-Qur'an dan shalat sunnah seperti shalat dhuha, agar siswa memiliki kedisiplinan termasuk kedisiplinan belajar sehingga kegiatan-kegiatan selain belajar seperti bermain game hanya sekedar pengisi waktu luang saja. Hal ini bisa terjadi jika guru bimbingan konseling Islam menanamkan penghayatan dan pemahaman serta pengamalan dari surah $\mathrm{Al}$ Ashar ayat 1-3 yang artinya, "Demi masa, sesungguhnya manusia itu benar-benar berada dalam kerugian, kecuali ornag-orang yang beriman dan mengerjakan amal saleh dan nasihat-menasihati supaya menaati kebenaran dan nasihat-menasihati supaya menetapi kesabaran".

Guru bimbingan konseling Islam dapat melakukan terapi kecanduan game online dengan proses tazkiyatun nufus (penyucian jiwa) dan tazkiyatun nuqud (penyucian pendapatan/ibadah sosial) dalam bentuk kegiatan silaturahmi, tausiyah, tasyrihah, dan tazkiyatun. Adapun penjelsannya disajikan pada Tabel 1.

Tabel 1. Terapi Kecanduan Game Online

Terapi Kecanduan Game Online Shilaturrahmi atau saling mengunjungi

Taushiyah atau ceramah agama

Tasyrihah

Tazkiyatun Nuqud

\section{Penjelasan}

Hal ini bisa diprogram dengan mengunjungi orang yang sakit dan orang yang dipenjara. Dengan mengunjungi orang yang sakit diharapkan siswa bisa mensyukuri nikmat sehat, sedangkan dengan mengunjungi penjara, diharapkan siswa bisa mensyukuri nikmat kebebasan dan berusaha tidak melakukan kejahatan.

Guru bimbingan konseling Islam memberikan layanan informasi melalui kegiatan bimbingan klasikal dengan materi yang berkaitan dengan tugas perkembangan remaja dengan mendasarkan pada ayat-ayat al-Qur'an dan hadis Rasulullah SAW.

Memohon kemudahan dan kelapangan dalam menerima nasihat dan ilmu pengetahuan. Guru bimbingan konseling Islam harus menanamkan keutamaan adab sebelum ilmu, seperti adab sebelum belajar, membiasakan membaca doa.

Pensucian pendapatan seseorang dengan jalan mengeluarkan sedekah dan zakat untuk menunjang hal-hal yang bermanfaat bagi masyarakat, yang dianggap sebagai pilar Islam. Hal ini sesuai dengan firman Allah dalam surah at-Taubah ayat 103, yang artinya "Ambillah zakat dari sebagian harta mereka, dengan zakat itu kamu membersihkan dan mensucikan mereka, dan berdoalah untuk mereka. Sesungguhnya doa kamu itu (menjadi) ketentraman jiwa bagi mereka. Dan Allah Maha Mendengar lagi Maha Mengetahui". Pelaksanaan kegiatan ini bisa dilakukan dengan bekerjasama dengan orang tua siswa. Terutama orang tua siswa yang kecanduan bermain game dan merokok. Setiap biaya yang dipakai untuk membeli kuota dan rokok dapat dialokasikan untuk memberikan infak dan 
sedekah kepada orang-orang yang membutuhkan. Hal ini diyakini menjadi sebab Allah SWT mencabut kecanduan tersebut dari hati dan pikiran siswa.

Dengan pendekatan bimbingan konseling Islam seperti yang dipaparkan pada Tabel 1 yang disertai dengan penciptaan suasana relegius di sekolah diyakini dapat membentuk generasi Islam yang unggul dalam kecerdasan intelektual, emosional dan spiritual. Sehingga pengaruh-pengaruh negatif kemajuan teknologi seperti kecanduan game online, medsos dan sebagainya dapat dikendalikan oleh siswa. Namun patut disadari bahwa saat ini tenaga bimbingan konseling khususnya tenaga bimbingan konseling Islam sangat terbatas, sehingga pada kesempatan ini penulis mengusulkan pengadaan jurusan Bimbingan Konseling Islam pada IAIN Watampone. Penulis meyakini prospek jurusan tersebut akan sangat baik, karena menjadi kebutuhan di sekolah atau madrasah. Karena bimbingan dan konseling adalah salah satu bagian integral dari pendidikan selain aspek administrasi dan supervisi serta aspek pembelajaran.

\section{SIMPULAN DAN SARAN}

\section{Simpulan}

Dari uraian tersebut di atas dapat disimpulkan bahwa bimbingan dan konseling Islami merupakan kegiatan proses bantuan yang diberikan kepada individu dalam memahami dirinya sendiri untuk menjalani tahap perkembangan menjadi manusia seutuhnya sebagaimana potensi yang dimilikinya sesuai petunjuk Allah dan sunnah Rasul. Selain itu, permasalahan mengakses internet yang tidak terkendali pada diri remaja dipengaruhi oleh beberapa faktor, diantaranya karena perkembangan remaja yang masih labil, ketidakmampuan mengendalikan kecanduan bermain game online menyebabkan siswa malas belajar sehingga prestasi akademik dan kualitas kesehatannya menurun. Bimbingan konseling Islami dengan metode yang bersumber dari al-Qur'an dan sunnah Rasulullah SAW seperti keteladanan Rasulullah SAW (modeling), conditioning, tazkiyatun nufus (penyucian jiwa) dan tazkiyatun nuqud (penyucian pendapatan/ibadah sosial) dapat menjadi solusi dalam mengatasi kecanduan game online.

Saran

Sebaiknya guru bimbingan dan konseling yang ada di sekolah dan madrasah menerapkan metodemetode yang berlandaskan al-Qur'an dan sunnah Rasulullah SAW. Untuk memenuhi kebutuhan guru bimbingan konseling Islam di sekolah-sekolah terutama di madrasah sebaiknya lembaga pendidikan pencetak tenaga pendidik seperti IAIN Watampone membuka jurusan Bimbingan Konseling Islam agar standar minimal tenaga pendidik di sekolah/madrasah yakni guru bimbingan konseling 1:150 siswa dapat terpenuhi.

\section{DAFTAR PUSTAKA}

Adz-Dzaky, M Hamdani Bakran, and Ahmad Norma-Permata. Psikoterapi \& Konseling Islam: Penerapan Metode Sufistik. Fajar Pustaka Baru, 2001.

Arifin, Isep Zainal. "Bimbingan Konseling Islam (Al-Irsyad Wa Al-Tawjîh Al-Islam) Berbasis Ilmu Dakwah." Ilmu Dakwah: Academic Journal for Homiletic Studies 4, no. 11 (2008): 27-42.

Cavanagh, M E, and J E Levitov. The Counseling Experience: A Theoretical Approach. Illinois: Waveland Press, 2002.

Dahlan, M D, and Dasar-Dasar Konseptual Penanganan Masalah-Masalah. "Bimbingan Dan Konseling Islami Di Bidang Pendidikan.” Yogyakarta: UII Press, 1987.

Kamaluddin, H. "Bimbingan Dan Konseling Sekolah." Jurnal Pendidikan Dan Kebudayaan 17, no. 4 (2011): 447-54.

Komarudin, K. "Mengungkap Landasan Filosofis Keilmuan Bimbingan Konseling Islam." International Journal Ihya"'Ulum Al-Din 17, no. 2 (2017): 209-32.

Laquey, Tracy. The User's Directory of Computer Networks. Elsevier, 2014.

Luddin, Abu Bakar M. Dasar Dasar Konseling. Perdana Publishing, 2010.

Nursalim, Mochamad, and S A Suradi. Layanan Bimbingan Dan Konseling. Surabaya: Unipress, 2002. Rahim Faqih, Ainur. Bimbingan Konseling Islam. Yogyakarta: UII Press, 2004.

Trisnani, Rischa Pramudia, and Silvia Yula Wardani. "Peran Konselor Sebaya Untuk Mereduksi 
Kecanduan Game Online Pada Anak.” Dialektika Masyarakat: Jurnal Sosiologi 2, no. 2 (n.d.): $71-80$.

Tumiyem, Tumiyem, and Dessy Nita Sembiring. "Program Bimbingan Dan Konseling Dalam Mengurangi Kecanduan Game Online Oleh Siswa Kelas VIII SMP Melati Binjai Tahun Pelajaran 2017/2018." Al-Irsyad 8, no. 1 (2018).

Wiguna, Ganda Yogi, and Yohanes Kartika Herdiyanto. "Coping Pada Remaja Yang Kecanduan Bermain Game Online.” Jurnal Psikologi Udayana 5, no. 3 (2018): 669-78. 